Viso - Cadernos de estética aplicada Revista eletrônica de estética

ISSN 1981-4062

№ 5, jul-dez/2008

http://www.revistaviso.com.br/
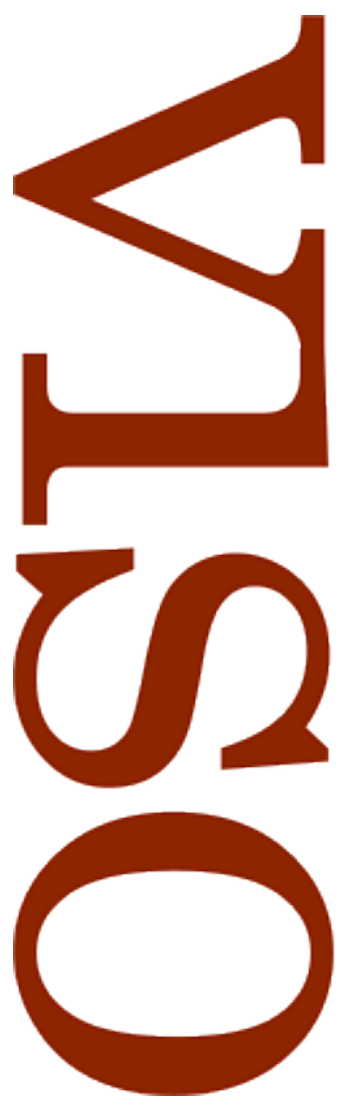

\title{
A morte da beleza (em Veneza): A dialética do esclarecimento segundo Pasolini e Visconti \\ Patrick Pessoa
}

Pontifícia Universidade Católica do Rio de Janeiro (PUC-Rio)

Rio de Janeiro, Brasil 


\section{RESUMO}

A morte da beleza (em Veneza):

A dialética do esclarecimento segundo Pasolini e Visconti

Este ensaio discute um possível conceito de "arte contemporânea" baseado na idéia de negatividade. Seu ponto de partida é uma análise da "dialética do esclarecimento" como apresentada nos filmes Medéia, de Pier PaoloPasolini, e Morte em Veneza, de Luchino Visconti.

Palavras-chave:

Adorno - Horkheimer - Pasolini - Visconti - arte contemporânea

\section{ABSTRACT}

The Death of Beauty (in Venice):

The Dialectic of Enlightenment according to Pasolini and Visconti

This essay discusses a possible concept of "contemporary art" based upon the notion of negativity. Its starting point is the analysis of the "Dialectic of Enlightenment" as it appears in Pier Paolo Pasolini's Medea and in Luchino Visconti's Death in Venice.

\section{Keywords:}

Adorno - Horkheimer - Pasolini - Visconti - contemporary art 
PESSOA, P. "A morte da beleza (em Veneza): A dialética do esclarecimento segundo Pasolini e Visconti". In: Viso: Cadernos de estética aplicada, v. II, n. 5 (jul-dez/2008), pp. 16-32.

DOI: $10.22409 / 1981-4062 / v 5 i / 62$

Aprovado: 09.12.2008. Publicado: 29.12.2008.

(c) 2008 Patrick Pessoa. Esse documento é distribuído nos termos da licença Creative Commons Atribuição-NãoComercial 4.0 Internacional (CC-BY-NC), que permite, exceto para fins comerciais, copiar e redistribuir o material em qualquer formato ou meio, bem como remixá-lo, transformá-lo ou criar a partir dele, desde que seja dado o devido crédito e indicada a licença sob a qual ele foi originalmente publicado.

Licença: http://creativecommons.org/licenses/by-nc/4.0/deed.pt_BR

Accepted: 09.12.2008. Published: 29.12.2008.

(C) 2008 Patrick Pessoa. This document is distributed under the terms of a Creative Commons Attribution-NonCommercial 4.0 International license (CC-BY-NC) which allows, except for commercial purposes, to copy and redistribute the material in any medium or format and to remix, transform, and build upon the material, provided the original work is properly cited and states its license.

License: http://creativecommons.org/licenses/by-nc/4.0/ 
Depois de O fim da história da arte?, livro publicado por Hans Belting em 1983 e republicado após uma extensa revisão em 1993 já sem o ponto de interrogação ao cabo do título, e do ensaio "O fim da arte", publicado por Arthur Danto em 1986 na coletânea O descredenciamento filosófico da arte, qualquer tentativa de formular um conceito de arte que torne possível compreender diferentes manifestações artísticas (contemporâneas) a partir de seus traços comuns tem de haver-se com uma forte desconfiança. Tal desconfiança não recai apenas sobre aqueles que insistem na defesa da idéia de progresso, que de fato muitas vezes pressupõe uma compreensão representacionalista e eurocêntrica da arte, mas sobre qualquer um que se deixe orientar menos pela tarefa de realçar diferenças do que de perceber semelhanças entre distintos fenômenos estéticos.

Mesmo reconhecendo a legitimidade dessa desconfiança, o propósito deste ensaio é discutir se a dialética do esclarecimento, como concebida por Adorno e Horkheimer, não seria um ponto de partida privilegiado para se forjar um conceito minimamente satisfatório de "arte contemporânea". Supondo que um recorte cronológico permanece ingênuo - será que um escritor como Josué Montello é mais contemporâneo do que Shakespeare? -, a questão que nos move é a seguinte: seria possível forjar um conceito de "arte contemporânea" que nos permitisse agrupar não apenas os mais célebres artistas do século XX - gente como Duchamp, Schönberg, Kafka, Brecht, Beckett e Godard -, mas também aqueles clássicos que, justamente por serem clássicos, permanecem contemporâneos?

A própria formulação dessa questão provavelmente causaria um riso universal entre os papas do atual mundo da arte, mas, se não é o escopo deste trabalho refutar teoricamente as suspeitas que alimentam um tal riso, decerto um de seus pressupostos é uma "suspeita da suspeita". Até que ponto o discurso acerca do "fim da (história da) arte" não se aproxima perigosamente do discurso do "fim da história", que, indissociável do discurso do "fim das ideologias", exatamente por isso aparece como ideologia barata, como a tentativa de naturalizar o neoliberalismo e assim inviabilizar qualquer transformação estrutural do sistema? Por mais que pareça apressada essa aproximação entre dois bordões, o do "fim da (história da) arte" e o do "fim da história", ${ }^{2}$ cujos pressupostos aparentemente são bastante diversos, não seria comum a ambos uma crença na "mão invisível do mercado" como única instância capaz de regular fenômenos estéticos ou econômicos que já não se deixariam mais enquadrar a priori em quaisquer classificações?

Uma vez que se admite uma certa desconfiança com relação ao potencial auto-regulativo do mercado (da arte), aliás mais do que justificada nestes tempos de crise (ou colapso) do sistema financeiro mundial, talvez não soe tão megalomaníaca - ou ingênua - a proposta deste texto. Para torná-la mais afinada com o seu objeto, a nossa tentativa de forjar um fio condutor para a apreciação daquilo que irmana diferentes obras de arte 
contemporâneas acompanhará os desdobramentos da dialética do esclarecimento à luz do modo como a relação entre mito e lógos, arte e ciência, é pensada por dois dos maiores cineastas do século XX: Pier Paolo Pasolini e Luchino Visconti.

\section{A dialética do esclarecimento}

Em sua Dialética do esclarecimento, obra publicada em 1947, Adorno e Horkheimer se propõem a analisar como o progresso tecnológico propiciado pela ciência moderna havia culminado não na emancipação do homem, ou na criação do paraíso sobre a terra que imaginara Francis Bacon, mas no minucioso "planejamento racional" do extermínio de seres humanos em escala industrial. Com a radicalidade de pensamento que thes é peculiar, Adorno e Horkheimer identificam a semente do "mal radical", na formulação de Kant, ou da "banalidade do mal", na formulação de Hannah Arendt, naquilo que os historiadores da filosofia, aliás de maneira bastante equivocada, costumam chamar de "passagem do mito ao lógos". O equívoco nessa expressão, "passagem", repousa sobre o fato de que ela implicitamente aponta para uma idéia de superação do mito pelo lógos, para uma idéia de progresso que, como veremos, é questionável.

Em todo caso, essa "passagem" remonta ao século VI a. C. e evoca imediatamente o nome de Xenófanes, que foi o primeiro filósofo pré-socrático a apresentar argumentos céticos que punham em relevo o caráter poético, imaginário, e, a seu ver, falso dos mitos como contados por Homero e Hesíodo. A partir de Xenófanes, cujas idéias "científicas" irão ressoar ainda no desprezo de Platão pelos artistas imitadores e na célebre expulsão dos poetas da cidade ideal, os mitos, passados de geração em geração na forma dos magníficos poemas épicos e trágicos que nos chegaram às mãos, não mais seriam a expressão do fundamento objetivo do mundo, de uma ordem cósmica regida pelos deuses, mas sim pura fantasia a uma enorme distância da verdade. Escreve Xenófanes, chamando a atenção para o caráter artificioso e culturalmente relativo, isto é, mentiroso, dos mitos: "Se os leões tivessem mãos e pudessem, com elas, pintar e fabricar obras como os homens, os leões pintariam figuras de deuses semelhantes a leões, e os bois figuras de deuses semelhantes a bois, cada espécie reproduzindo a sua própria forma". ${ }^{3}$ E em outro fragmento: "Os deuses dos etíopes são negros e têm o nariz chato. Os deuses dos trácios são ruivos e têm os olhos azuis". ${ }^{4}$

Se, até então, para os gregos eram os deuses que criavam os homens, a partir de Xenófanes tornar-se-á claro que são os homens que criam os deuses e que portanto os deuses nunca foram mais do que ficções de poetas. Quando atentamos para o fato de que, até então, os mitos, isto é, as obras de arte através das quais eles eram transmitidos, apareciam como a mais elevada expressão da verdade, compreendemos o quão radical foi essa ruptura. Afinal, se antes, ao se enxergarem como criaturas ou mesmo marionetes dos deuses, os homens não tinham qualquer liberdade para moldar o seu destino, ao passarem de criaturas a criadores dos deuses, os homens se viram na 
iminência de desenvolver uma nova forma de pensamento, o pensamento racional, o lógos, que Ihes permitiria assenhorarem-se do universo.

O problema é que, como escrevem Adorno e Horkheimer logo no início da Dialética do esclarecimento: "No sentido mais amplo do progresso do pensamento, o esclarecimento tem perseguido sempre o objetivo de livrar os homens do medo e de investi-los na posição de senhores. Mas a terra totalmente esclarecida resplandece sob o signo de uma calamidade triunfal". ${ }^{5}$ Essa observação pode ser traduzida através da seguinte pergunta: como é que o desenvolvimento do lógos grego e, a partir dele, da ciência moderna, que deveria emancipar o homem de seus mais arcaicos medos e torná-lo senhor da natureza, acabou por gerar um fenômeno como Auschwitz?

A essa pergunta, para nos mantermos próximos ao tema deste ensaio, seria ainda possível acrescentar as seguintes: não haveria uma relação entre o desenvolvimento da ciência e da técnica modernas, herdeiras da racionalidade grega - ainda que não idênticas a ela - e a arte contemporânea? Supondo que o fenômeno Auschwitz é o fenômeno mais importante da história contemporânea, pensar as condições que o prepararam não seria indispensável para pensar a arte contemporânea, que sempre dialoga com Auschwitz e os descaminhos da ciência moderna mesmo quando não se apercebe disso?

\section{"Tudo é santo": A relação entre arte e ciência segundo Pasolini}

Em uma espécie de prólogo a seu filme Medéia, lançado em 1969, Pasolini nos fornece uma belíssima interpretação da diferença entre o mito e o lógos, entre o pensamento mágico (ou imagético) e o pensamento lógico (ou conceitual). Apresenta-nos um longo monólogo de Quíron, centauro que foi o mestre de tantos heróis da mitologia grega, endereçado a Jasão, um de seus mais célebres pupilos. $O$ interessante nesse longo monólogo é que ele é claramente dividido em três partes: na primeira, o centauro fala a Jasão quando este tem 5 anos; na segunda, a Jasão quando este já tem 13 anos; na última, coerentemente com a lição final que tem a transmitir, o mesmo ator que vivia o centauro aparece transformado em um ser humano e, como seria de se esperar, fala a um Jasão adulto. Vale a pena reproduzir na íntegra o referido monólogo e refletir sobre a seguinte questão, central para a compreensão da dialética do esclarecimento: segundo Pasolini ${ }^{6}$, o que já haveria de lógico nos mitos (e na arte) e o que continua havendo de mítico no lógos (e na ciência)?

O CENTAURO QUíRON (fala a Jasão, um menino de cinco anos): Hoje você completa cinco anos e vou the dizer a verdade: você não é meu filho. Não o encontrei no mar. Foi tudo mentira o que Ihe contei. Você não é mentiroso, mas eu sou. Me diverte contar mentiras. Você fica triste de saber que não é meu filho, que eu não sou nem seu pai nem sua mãe? Tudo começou por causa de um carneiro com pele de ouro. Sim, de um carneiro que falava, que era divino. Zeus o tinha dado a Néfele, aquela que rege as nuvens, porque Néfele tinha de salvar os seus filhos. Tinha que salvá-los porque Ino 
queria matá-los. Ino era filha de Cadmo e segunda mulher do rei dos Orcomenos, que se chamava Atamante. Atamante era filho de Éolo, aquele que rege os ventos, do qual, antes, Ino havia sido esposa. Bem, foi apenas uma questão de ciúmes. O carneiro do qual the falei, que tinha a pele de ouro, conseguiu levar para além-mar um dos dois filhos de Néfele, que se chamava Frixo. Ele chegou na cidade do rei Éetes, que era filho do Sol. Este rei acolheu Frixo e sacrificou ao deus Zeus o carneiro com a pele de ouro, para agradecer-lhe. Os descendentes de Éolo fizeram tudo para reconquistar aquele velocino, porque dava sorte aos reis. Garantia que o reino deles jamais acabaria e que tudo ficaria sempre como antes. Fizeram de tudo, mas não conseguiram. Não conseguiram! E você, filhote, é um descendente de Éolo, porque é filho de um filho daquele Atamante de que te falei antes, e que era rei de lolco, uma cidade vizinha daqui, muito rica em ovelhas e em grãos, que são propriedade do rei. Seu tio Pélias mandou prender o seu pai e se apossou do reino, que é seu por direito, e eu fiquei com você aqui, em segurança. Entendeu? É verdade, é uma história um pouco complicada, porque é feita de coisas e não de pensamentos.

O CENTAURO QUÍRON (fala a Jasão, um jovem de treze anos): Tudo é santo. Tudo é santo. Tudo é santo. Não há nada de natural na natureza, meu pequeno. Guarde isso na memória. Quando a natureza lhe parecer natural, tudo terá acabado e começará qualquer coisa outra. Adeus céu, adeus mar. Que belo o céu! Próximo. Feliz. Diga, te parece mesmo que algum pedacinho dele seja natural e que não pertença a um deus? Assim como o mar, neste dia em que você completa 13 anos, e pesca com os pés na água morna. Olhe atrás de você. O que vê? Talvez alguma coisa de natural? Não! É uma aparição o que você vê atrás de você. Como as nuvens que se espelham na água parada, pesada, das três da tarde. Olhe lá longe aquela tira negra sobre o mar, brilhante como o azeite. Aquelas sombras de árvores e aqueles canaviais. Em cada ponto que seus olhos vêem, está escondido um deus. E se por acaso não está, aí deixou sinais de sua presença sagrada. Ou silêncio, ou cheiro de erva, ou frescor de água doce. Sim, tudo é santo, mas a santidade traz consigo uma maldição. Os deuses que amam também odeiam.

“QUÍRON” JÁ TRANSFORMADO EM SER HUMANO (fala a Jasão, já adulto): Talvez você tenha achado que, além de mentiroso, fui também excessivamente poético. Mas o que quer? Para o homem antigo, os mitos e os rituais são experiências concretas que ele compreende até em seu existir corporal e cotidiano. Para ele a realidade é uma unidade tão perfeita, que a emoção que sente, digamos, frente ao silêncio de um céu de verão equivale totalmente à mais interior experiência pessoal de um homem moderno. Você irá até seu tio, usurpador do seu reino, para reclamar os seus direitos. E ele, para te eliminar, precisará de algum pretexto. Poderá te mandar realizar alguma missão, como a reconquista do velo de ouro, por exemplo, e assim você irá para um país distante, além-mar. Ali, conhecerá um mundo muito distante do uso da nossa razão. Como você poderá ver, a vida desse mundo é muito realista, porque só o que é mítico é realista, e tudo que é realista é mítico. Isso, pelo menos, é o que prevê esta nossa divina razão. O que ela não pode prever, infelizmente, são os erros aos quais conduzirá você. E quem sabe quantos serão! O que o homem, descobrindo a agricultura, viu nos cereais, o que aprendeu desta relação, o que compreendeu do exemplo das sementes, que perdem a forma debaixo da terra para renascer, tudo isso representou a lição definitiva, a ressurreição, meu caro. Mas agora essa lição definitiva já não serve mais. $\mathrm{O}$ que você vê nos cereais, o que entende do renascer das sementes, para você agora não tem mais nenhum significado, como uma remota recordação que já não lhe diz mais respeito. De fato, não existe nenhum deus. ${ }^{7}$ 
A riqueza desse monólogo torna-se ainda mais evidente quando o ouvimos acompanhado pelos belos enquadramentos de Pasolini, que opta por planos muito abertos dos personagens em meio à pujança divina da natureza. Como, no entanto, foge ao escopo deste texto uma análise detalhada do filme Medéia, basta-nos por ora sublinhar as três principais características do discurso de Quíron que iluminam a dialética do esclarecimento como compreendida pelo cineasta:

1. O mito narrado por seu mestre transmite ao pequeno Jasão o lugar, pré-figurado por sua família, que ele deverá ocupar na ordem cósmica. Essa história de seus ancestrais, por mais intrincada que possa ser, não apenas explica a sua origem, o que é o sentido propriamente epistemológico dos mitos, mas simultaneamente Ihe dá uma tarefa, um destino, o que é o sentido propriamente ético dos mitos. Em outras palavras: além de explicar o funcionamento do universo, os mitos dão sentido e valor à vida de cada ser vivo - preocupação estranha à ciência (moderna).

2. Não há melhor definição da compreensão mítica do mundo do que o discurso em que o centauro repete três vezes que "tudo é santo" e arremata: "Não há nada de natural na natureza. Quando a natureza lhe parecer natural [note-se que este é o traço fundamental do pensamento racional] tudo terá terminado e começará qualquer coisa outra". Esse trecho aponta para a pressuposição fundamental do mito: o universo tem (ou é) uma ordem sagrada e cada ínfima parte do universo deve estar intimamente harmonizada com o todo.

3. Finalmente, o discurso do ator reconvertido em homem, pois que agora visto sob a ótica de um Jasão adulto, que teria abandonado aquela infância poética da humanidade, explica "de fora" o sentido dos mitos para as sociedades arcaicas: "Além de mentiroso, talvez você tenha me achado excessivamente poético. Mas, para o homem antigo, os mitos são uma coisa concreta, e eles o compreendem até em seu existir corporal e cotidiano. Para ele, a realidade é uma unidade tão perfeita que a emoção que sente, digamos, frente ao silêncio de um céu de verão, equivale totalmente à mais interior experiência pessoal de um homem moderno".

Sintetizando-se essas três dimensões do mito como compreendidas por Pasolini, entende-se como o cineasta se aproxima dos filósofos da escola de Frankfurt. Para ele, os mitos já levavam a cabo o esclarecimento do mundo antes do advento da razão, constituindo-se como uma outra episteme. Os mitos, entretanto, seriam superiores à razão moderna porque facultariam a cada homem a experiência da realidade como uma unidade perfeita, uma totalidade em que cada fragmento teria o seu lugar sagrado e se harmonizaria com todos os demais. Essa unidade perfeita, essa "síntese não-violenta do diverso", além disso, seria vivida concreta e corporalmente, sem depender da mediação dos conceitos, esses imperfeitos consolos metafísicos. 
Essa compreensão da "racionalidade" superior inerente aos mitos, promessa de uma totalidade epistemológica e de uma significação existencial absolutamente vedadas ao discurso científico moderno, entretanto, confronta Pasolini com a seguinte questão: por que o homem ocidental teria abandonado essa infância paradisíaca? Que miragem o teria seduzido para além do "mundo fechado dos gregos", em que, no dizer de Lukács, "as perguntas eram respondidas antes mesmo de serem formuladas"? ${ }^{8}$

Deixando-se de lado os fatores históricos que precipitaram essa revolução, como o advento da democracia ateniense, é o próprio centauro Quíron que nos responde, no momento que antecede imediatamente à sua desmitologização. Depois de se regozijar com a percepção de que "em cada ponto que os teus olhos enxergam está escondido um deus", o centauro constata amargamente: "Sim, tudo é santo, mas a santidade traz consigo uma maldição. Os deuses que amam também odeiam".

Para escapar ao jugo dos deuses, ao medo do imponderável, das irrupções do sobrenatural no mundo, que estão sempre na iminência de fazerem naufragar os projetos humanos, os homens teriam renunciado, ao menos nessa mítica reconstrução de Pasolini, ao seu sentimento de unidade com o cosmos, isto é, com os deuses. Os homens, em algum momento de sua história, não teriam mais suportado a vizinhança desses seres paradoxais, a um só tempo terríveis em sua arbitrariedadeimprevisibilidade-violência e mantenedores da ordem do universo, ou melhor, do universo como ordem. Como uma ordem, eis o sentido grego da palavra "cosmos", dotada de beleza, idéia que sobrevive na palavra "cosmético". Embelezar-se, segundo essa acepção, seria dar ordem à própria fisionomia, fazendo com que cada uma de suas mais ínfimas partes harmonize-se com o todo, sem distorções ou dissonâncias.

Conclui o ex-centauro, agora reduzido a reles mestre-escola, na alegoria pasoliniana: "O que o homem, descobrindo a agricultura, viu nos cereais, o que aprendeu desta relação, o que compreendeu do exemplo das sementes que perdem a forma debaixo da terra para renascer, tudo isso representou a lição definitiva, a ressurreição, meu caro [isto é, o nascimento para um novo modo de pensamento, o logos]. Mas agora esta lição definitiva [a contribuição da ciência para o controle tecnológico do homem sobre a natureza e o incremento de sua capacidade de previsão e de utilização de todas as reservas naturais, com a correlata conversão da natureza em reserva] não serve mais [não tem qualquer significação existencial]. O que você vê nos cereais, o que entende do renascer das sementes, para você agora não tem mais nenhum significado, como uma remota recordação que não the diz mais respeito. Com efeito [conclui um homem irremediavelmente contemporâneo, ainda que trajado como um grego antigo], não existe nenhum deus". 


\section{A morte da beleza: A relação entre ciência e a arte segundo Visconti}

Ainda que um certo laivo de melancolia perpasse as últimas palavras do ex-centauro, as conseqüências da Queda do homem em um mundo dessacralizado, do qual os deuses, isto é, do qual o sentido está ausente, só ficam claras em um outro filme, Morte em Veneza, de Luchino Visconti, baseado no romance homônimo de Thomas Mann. Nesse filme, a articulação entre ciência e arte ilumina o outro lado da dialética do esclarecimento, justo aquele que fica parcialmente encoberto no filme de Pasolini. Se já se mostrou de que modo a pressuposição de uma ordem cósmica, assim como a tentativa de explicá-la e de obter algum controle sobre a "natureza sobrenatural", é o aspecto iluminista que sempre subjaz às narrativas míticas, restaria agora esclarecer onde repousa o núcleo mítico da razão moderna. Este núcleo mítico aparece com clareza na narrativa do ocaso de Gustav von Aschenbach, cujo sobrenome significa literalmente "ribeiro de cinzas", mas que, sendo compositor (na adaptação feita por Visconti), decerto evoca simultaneamente "as cinzas de Bach" - compositor clássico que já não seria mais possível imitar na modernidade - e as dores de Gustav Mahler, cuja música pontua todo o filme.

Aschenbach, que no romance de Mann era um escritor, aparece no filme de Visconti como um célebre compositor em crise que, abandonado pelo público e com problemas coronarianos, vai buscar nas praias de Veneza um bálsamo para o seu tormento. Os três elementos que sustentam todos os desdobramentos do filme são a aparição de Tadzio, um jovem polonês de catorze anos pelo qual o velho compositor se apaixona; o siroco veneziano, que torna o ar da cidade irrespirável e traz consigo a peste - a cólera asiática - e o caos; e as discussões em flashback entre Aschenbach e seu amigo Alfred, personagem ausente do romance de Mann, no qual os mais íntimos conflitos do artista e a ambigüidade no modo como ele concebe a beleza assumem a forma de longos monólogos - ou diálogos - interiores narrados em terceira pessoa.

A articulação entre esses três elementos, a princípio pouco evidente, vai ganhando corpo ao longo do filme quando se percebe que Aschenbach só se apaixona por Tadzio porque o jovem corporifica o ideal de beleza por ele buscado em suas obras. Visconti, como é sabido, entrevistou mais de dois mil garotos para encontrar o ator que viveria Tadzio em seu filme ${ }^{9}$, o qual precisava adequar-se à seguinte descrição do personagem, feita por Mann em seu livro:

Aschenbach notou com espanto que o rapaz era de uma beleza perfeita. Seu rosto pálido, graciosamente reservado, emoldurado por cabelos anelados cor de mel, o nariz reto, a boca adorável, a expressão de seriedade afável, digna de um deus, lembravam uma escultura grega do período áureo, sendo que à mais pura perfeição da forma aliava-se um encanto pessoal tão exclusivo que o observador acreditava jamais ter encontrado, quer na natureza, quer nas artes plásticas, algo que se aproximasse de um acabamento tão feliz. ${ }^{10}$ 
Nessa descrição, em que a "beleza perfeita" de Tadzio remete Aschenbach diretamente a um deus grego, ou melhor, a uma "escultura grega do período áureo", torna-se evidente a concepção de beleza por ele abraçada, antes espiritual do que sensorial, só podendo ser alcançada através da "paixão fria", do rigor e da disciplina do artista, o qual deve ser antes de tudo um consciencioso artesão. Sentimentos, tanto para Aschenbach quanto para Tonio Kröger ${ }^{11}$, devem ser deixados aos diletantes. $O$ que caracterizaria os verdadeiros artistas é o seu autocontrole, a capacidade de purificar suas obras de tudo o que não é essencial.

Isso, pelo menos, é o que nos atesta essa outra passagem de Morte em Veneza, que corrobora que a paixão de Aschenbach por Tadzio, se em alguma medida é a de um velho sátiro por um menino, não pode ser dissociada da paixão de um artista pelo seu modelo ideal, de um criador pela criatura que, mais do que qualquer outra, gostaria de ter trazido à luz:

Que disciplina, que precisão de pensamento se exprimiam nesse corpo distendido e na plenitude de sua perfeição juvenil! Mas a vontade rigorosa e pura que, misteriosamente, conseguira trazer à luz essa obra de arte divina - ele, o artista, não a conhecia, não the era familiar? Não era ela que também atuava nele, quando, tomado da mais sóbria paixão, libertava da massa marmórea da linguagem a forma esguia que visualizara em espírito e que apresentava à humanidade como imagem e espelho da beleza espiritual? Imagem e espelho! Seus olhos abraçaram a nobre figura ali, à beira do azul, e num êxtase delirante acreditou captar com esse olhar o Belo em si, a forma enquanto pensamento divino, a perfeição única e pura que habita o espírito e da qual se erigira ali uma cópia humana, um símbolo leve e gracioso para adoração. ${ }^{12}$

Visconti, em seu filme, optará por uma apresentação mais didática (do que a de Thomas Mann) da contraposição entre a concepção clássica de beleza defendida por Aschenbach e a concepção de beleza, que se poderia dizer romântica, defendida por Alfred, personagem (inexistente no livro) que pode ser visto como a corporificação do super-ego do compositor. Todo o diálogo abaixo é narrado em off, enquanto Aschenbach, jantando, observa a beleza de Tadzio, à mesa com sua família:

Alfred: Beleza. Quer dizer, o seu conceito "espiritual" de beleza.

Gustav von Aschenbach : Mas você nega a habilidade de o artista criar a partir do espírito?

A: Sim, Gustav, isso é precisamente o que eu nego.

G: Então, a seu ver, o nosso trabalho como artistas é...

A: Trabalho! Exatamente. Você realmente acredita que a beleza possa ser o produto do trabalho?

G: Sim... sim, eu acredito.

A: É assim que a beleza nasce. Assim, espontaneamente, indiferente ao seu trabalho e ao meu. Ela preexiste à nossa presunção de sermos artistas. ${ }^{13}$

Após o jantar, enquanto caminha e fuma pela varanda do hotel, Aschenbach continua se lembrando da conversa com Alfred. A voz em off logo cederá lugar a uma cena entre os dois, ocorrida em algum lugar do passado. 
A: Seu grande equívoco, meu caro amigo, é considerar a vida, a realidade, como uma limitação.

G: E ela não é exatamente isso? A realidade apenas nos distrai e degrada. Sabe, às vezes eu penso que os artistas se parecem mais com caçadores que atiram no escuro. Não sabem qual é o seu alvo, nem tampouco se o atingiram. Mas não se pode esperar que a vida ilumine o alvo e estabilize a sua mira. A criação da beleza e da pureza é um ato espiritual.

A: Não, Gustav. Não! A beleza pertence aos sentidos. Somente aos sentidos!

G: Você não tem como alcançar o espírito... Você não tem como alcançar o espírito através dos sentidos. É somente através do absoluto controle dos sentidos que se pode, algum dia, alcançar sabedoria, verdade e dignidade humana.

A: Sabedoria? Dignidade humana? Para que servem? O gênio é uma dádiva divina.

Não! Uma aflição divina. Uma chama breve e pecaminosa de dons naturais.

G: Eu rejeito, eu rejeito as virtudes demoníacas da arte!

A: E você está errado! ${ }^{14}$

Feita essa apresentação dos pressupostos estéticos que alimentam a paixão de Aschenbach por Tadzio, cabe retomar o enredo do filme de Visconti, ao longo do qual se tornará clara toda a ambigüidade que move o artista em seu afã pela beleza. Se, por um lado, Aschenbach reconhece no garoto a corporificação de seu ideal estético, a beleza clássica mais perfeita, andrógina, dessexualizada, por outro o ímpeto que o arrasta em direção a ele é radicalmente sensual, instintivo, incontrolável. Se, por um lado, Tadzio, "belo como um deus, era uma visão que inspirava concepções míticas" ${ }^{15}$, por outro o pendor do artista a um retorno àquele "início poético dos tempos" ${ }^{16}$, àquela unidade entre eu e mundo que teria existido na Grécia não teria como não arrastá-lo ao desastre. Como um artista tão consciencioso e disciplinado podia permanecer inconsciente do abismo que o separava de Tadzio? Como podia permanecer cego para o fato de que, por mais que se esforçasse em sua tentativa de se aproximar do Belo, mais o Belo dele se esquivava? É sintomático, por exemplo, o fato de Tadzio ser polonês e Aschenbach não compreender a sua língua, a linguagem da beleza...

Em um último afã por seduzi-lo, por colocar-se à altura da beleza como ele a compreendia, o velho compositor recorre inclusive aos cosméticos - mascara o seu cabelo grisalho com uma tinta exageradamente preta, pinta os lábios com batom vermelho, o rosto com uma pomada branca que visava a encobrir suas rugas, veste-se de branco e coloca uma rosa na lapela -, mas é tudo em vão. Ainda uma vez, caminhando em meio a uma Veneza tomada pela peste e o cheiro da morte, Tadzio dele se esquiva e Aschenbach fica prostrado em meio ao caos, com a tinta do cabelo the escorrendo pelo pescoço e lágrimas sulcando sua grossa máscara branca. Entre esse fim anunciado e a morte do compositor à beira da praia, Aschenbach lembra-se ainda de um diálogo com Alfred, que, tendo ocorrido imediatamente após o fracasso de sua última obra e assim agravado seus problemas no coração, nos ajuda a compreender afinal o que morre em Veneza.

A: Seu trapaceiro, seu magnífico vigarista!

G: O que mais eles querem de mim?

A: Pura beleza. Severidade absoluta. Pureza da forma. Perfeição. A abstração dos 
sentidos! Tudo se foi! Nada restou! Nada! A sua música nasceu morta e você está desmascarado.

G: Alfred, mande-os embora. Por favor, faça com que saiam.

A: Mandá-los embora?! Vou entregá-lo a eles!

G: Não, Alfred, por favor. Não faça isso, por favor. Não, por favor. Não...

A: A eles! Eles vão julgá-lo. E eles vão condená-lo.

G: Não, Alfred, não.

Tendo a risada sardônica de Alfred como pano de fundo, Gustav, em sua cama no hotel veneziano, parece despertar de um pesadelo. Ele berra "Não!" desesperadamente. A voz de Alfred entra em off.

A: Sabedoria. Verdade. Dignidade humana. Está tudo acabado. Agora, não há mais razão para que você não vá para o túmulo, levando sua música. Você alcançou o perfeito equilíbrio. O homem e o artista são um só. Chegaram juntos ao fundo do poço. (Aschenbach olha o relógio de bolso na cabeceira da cama.) Você nunca possuiu castidade. A castidade é o dom da pureza e não o doloroso resultado da velhice. E você está velho, Gustav. E, em todo o mundo, não há impureza mais impura do que a velhice. ${ }^{17}$

Seguindo o fio condutor da dialética do esclarecimento, é possível conjeturar que o que morre em Veneza é uma compreensão do artista como sendo essencialmente um técnico habilidoso, um homem absolutamente disciplinado e votado à construção matemática de sua arte, da qual deveriam ser excluídos todos os elementos inessenciais, isto é, impuros. Juntamente com esse artista, morre também em Veneza a concepção de beleza de Aschenbach, que um dos baluartes do Classicismo, Boileau, assim definiu: "Em uma obra de arte, é necessário que cada elemento seja posto em seu devido lugar; que o começo e o fim se harmonizem com o meio; que, com uma arte exigente, as peças adequadas não formem senão um único todo de diversas partes...." ${ }^{18}$

A morte desse artista e dessa concepção de beleza (como harmoniosa totalidade alcançada através de uma obediência às regras da arte) é que dará lugar, posteriormente, ao advento do gênio romântico, tempestuoso e apaixonado, que não cuida mais de quaisquer regras de composição previamente existentes e deixa-se tomar pelos frutos que a natureza e as sensações lhe entregam. $O$ artista romântico, não obstante, continuaria sendo um "artesão", um técnico que, apenas no alvorecer da contemporaneidade, finalmente dará lugar a um outro tipo de artista, o assim chamado "artista contemporâneo".

Embora seja temerária qualquer tentativa de estabelecer um modelo de "artista contemporâneo", é possível afirmar que a exigência de um domínio das técnicas, indispensáveis ao manejo de um material determinado (tinta, madeira, pedra ou palavra), não é mais tão decisiva como foi no passado. Muitas vezes, o artista contemporâneo afirma-se orgulhosa e galhardamente como aquele que "não sabe fazer nada", assim rejeitando o tradicional parentesco entre domínio técnico e valor estético. Abrindo mão de se deixar determinar pelo domínio técnico no manejo de um material específico, o "artista contemporâneo" pode então trabalhar com os mais diversos materiais pré-formados, com 
as ruínas, os restos, os fragmentos dos distintos objetos que lhe chegam às mãos. $O$ mais decisivo para a sua caracterização, entretanto, é que, com esses materiais, não pretende mais criar nenhuma totalidade fechada. Pretende, ao contrário, ostentar a fragmentação do mundo moderno na fragmentariedade de sua própria obra. Dessa premissa, nascem boa parte das instalações, como por exemplo - já que estamos falando aqui sobretudo de cinema - a nave espacial conceitual com dezenas de elementos que não se deixam integrar em uma totalidade que encerra Oito e meio, de Fellini. Ou os multifacetados monólogos interiores dos cidadãos da Berlim de Asas do desejo, de Wim Wenders, que nem mesmo a perspectiva transcendente dos anjos é capaz de harmonizar.

Se articularmos, agora, as concepções da dialética do esclarecimento presentes nos filmes de Pasolini e Visconti aqui comentados, torna-se patente que o que sucumbe em Veneza, assassinada pela peste e por um mundo inteiramente fora dos eixos, é uma compreensão da arte como substituta dos mitos, uma compreensão da arte como independente da história e refratária a ela. No filme de Visconti, fica muito claro que, em meio a um tempo empesteado como o de Aschenbach, o propósito "racionalista" de reconstruir a realidade como uma totalidade fechada, tecnicamente controlada, orgânica, pura, perfeita, só pode aparecer como uma perigosa tentativa de galvanização da experiência grega do mundo. Uma experiência da qual, nós, contemporâneos, estamos definitivamente apartados, mas que um "pintor" austríaco, mobilizando as técnicas mais modernas, tentou ressuscitar. Adolf Hitler, para alcançar a unidade perfeita que caracterizaria a "obra de arte total" [Gesamtkunstwerk] que pretendia criar, "o povo alemão" ou "o Reich de mil anos", na qual todos os elementos dissonantes deveriam ser simplesmente eliminados em nome da preservação de uma harmonia e de uma organicidade (hoje) impossíveis, construiu em Auschwitz e em diversas outras cidades da Europa o seu leito de Procusto. Se, naquele momento, a cama de ferro nazista acabou sendo destruída pelas bombas dos Aliados, até hoje ela ainda assume as mais diversas configurações nas principais manifestações da indústria cultural.

Hitler, sob essa ótica, não foi o único a almejar uma restauração do mundo fechado de Quíron, não foi o único herdeiro da nostalgia de Aschenbach, não foi o único a não reconhecer a morte da beleza, corolário inevitável do afastamento dos deuses. Muitos outros herdeiros dessas personagens continuam vivendo entre nós - e talvez mesmo em nós. Essa suspeita ajuda-nos a compreender aquela célebre passagem das teses "Sobre o conceito de história" de Walter Benjamin: "O assombro com o fato de que os episódios que vivemos no século XX 'ainda' sejam possíveis não é um assombro filosófico. Ele não gera nenhum conhecimento, a não ser o conhecimento de que a concepção da história da qual emana semelhante assombro é insustentável". ${ }^{19}$ Ajuda-nos, também, a mais uma vez experimentar a atualidade da exortação que o mesmo filósofo nos legou ao cabo de seu texto sobre "A obra de arte na era de sua reprodutibilidade técnica", redigido em 1933: "Eis a estetização da política, como a pratica o fascismo (e os donos de agências de publicidade em geral). O comunismo responde com a politização da arte". ${ }^{20}$ 


\section{Epílogo: duas ou três coisas que sei sobre ela}

Como se reconhecem as manifestações artísticas contemporâneas? Eis a pergunta que motivou a redação deste ensaio. Se, por um lado, essa pergunta não tem como receber uma resposta unívoca, já que isso pressuporia uma violência excessiva no uso do mecanismo de identificação inerente ao pensamento conceitual, por outro lado a constatação da dificuldade intrínseca à sua formulação - e ainda mais à(s) sua(s) resposta(s) - não poderia nos fazer recuar, sob o risco de nos vermos reféns do que se poderia chamar de "ditadura da diferença". Caminhando sobre o fio da navalha entre um empirismo ingênuo ou cronológico, cujo pressuposto é uma crença desmedida no mercado (da arte), e a arrogância dos forjadores de conceitos que se julgam senhores da verdade, acabamos optando por um desvio. Ao tentarmos nos acercar da arte contemporânea negativamente, a partir de sua contraposição à poesia épica grega segundo a interpretação de Pasolini e de sua contraposição à poética neo-clássica abraçada por Aschenbach no filme de Visconti, tornou-se para nós possível sustentar a hipótese, aliás nada original, de que o traço mais marcante das manifestações artísticas contemporâneas é a sua negatividade. ${ }^{21}$

Em primeiro lugar, essa negatividade é o índice de um situação histórica que se tornou excessivamente opaca, já que os mecanismos de poder encontram-se cada vez mais disseminados e despersonalizados, de modo que seria ingênuo uma obra de arte pretender desmascarar uma ideologia, conservando aquela velha pretensão, ainda acalentada por um artista fortemente iluminista como Brecht, de mostrar a verdade sobre as relações sociais de poder. Essa verdade, como nas parábolas de Kafka ou nas peças de Beckett, atualmente só pode ser exposta quando se reconhece a impossibilidade de figurá-la diretamente. Assim, entende-se por que tantos artistas contemporâneos apostam no absurdo e na interrupção do movimento esperado - caso da dança contemporânea, por exemplo - como índice de sua fidelidade à nossa situação histórica.

Em segundo lugar, essa negatividade pode ser entendida como uma resistência ao império do sentido e do mecanismo de identificação que regula o pensamento conceitual. Afinal, como já entenderam muitos artistas desde o começo do século XX, a atribuição de um significado a uma mercadoria é condição de possibilidade para a atribuição de um valor, isto é, de um preço de mercado. Outra condição para a atribuição de um preço de mercado é a própria noção de obra como um objeto que possa ser vendido. Por isso, desde a década de 1960, as performances e os happenings tornaram-se tão importantes no panorama do mundo da arte. Como aconteciam uma única vez, a proposta era fazer essas manifestações resistirem à sua imobilização na forma-mercadoria. Se, no final das contas, com a criação dos múltiplos tipos de registros desses acontecimentos, os artistas acabaram perdendo sua batalha contra o mercado - não importa aqui o quanto tenham desejado ardentemente essa derrota, essa incorporação... -, sua derrota ao menos serviu para trazer novamente à berlinda a questão da relação entre arte de vanguarda e política. $^{22}$ 
Em terceiro lugar, os artistas contemporâneos estão muito atentos às conseqüências deletérias da fetichização da técnica e da eficiência, da disciplina e da ordem, cujo monumento-mor foram os campos de concentração nazistas. Daí a substituição dos artistas-artesãos pelos artistas-filósofos, que imprimem em uma realidade previamente existente uma idéia que as transfigura. Duchamp permanece como o mestre inigualável nesse tipo de manifestação, os ready-mades. ${ }^{23}$

Finalmente, e essa me parece ser a conseqüência ético-política mais radical na aposta de alguns artistas contemporâneos em uma fidelidade irrestrita à autonomia da obra de arte, a negatividade de diversas manifestações artísticas contemporâneas pode acabar por acostumar os espectadores a um encontro prazeroso com o que não tem função, com o que não se deixa instrumentalizar, com o inteiramente outro, servindo como ponto de partida para que o encontro com o outro não precise ser necessariamente traumático, ou bem gerando a necessidade de evitá-lo, ou bem a necessidade de eliminá-lo, como fizeram os nazistas e continuam a fazer os nossos capitães Nascimento.

\section{* Patrick Pessoa é pós-doutorando em filosofia pela PUC/RJ.}

A bolsa de pesquisa do CNPq referente a meu pós-doutorado na PUC/RJ foi imprescindível para a elaboração deste texto.

${ }^{1}$ ADORNO, T. Ästhetische Theorie. Frankfurt am Main: 2003, p. 168.

${ }^{2}$ Para fundamentar essa aproximação entre os discursos acerca do fim da história da arte e do fim da história, seria possível recorrer à autoridade de Arthur Danto, que escreveu o seguinte: "[...] eu gostaria de acreditar que, com as Brillo boxes, a história da arte de certo modo chegou ao fim. Ela não parou [stopped], mas sim acabou [ended], no sentido de que alcançou uma espécie de consciência de si e tornou-se, sob certa perspectiva, a sua própria filosofia: um estado de coisas previsto na filosofia da história de Hegel" (DANTO, A. The transfiguration of the commonplace. Cambridge: Harvard University Press, 1981, p. vii).

${ }^{3}$ XENÓFANES. "Fragmentos." In: BORNHEIM, G. (org). Os filósofos pré-socráticos. Tradução de Gerd Bornheim. São Paulo: Cultrix, 1983, p. 33.

${ }^{4}$ Ibidem, p. 34.

${ }^{5}$ ADORNO, T; HORKHEIMER, M. Dialética do esclarecimento. Tradução de Guido Antônio de Almeida. Rio de Janeiro: Jorge Zahar Editor, 1985, p. 19.

${ }^{6}$ Ao falarmos na "dialética do esclarecimento segundo Pasolini", de forma alguma pretendemos operar uma redução da complexa filosofia da história de Pasolini à posição de Quíron, que é apenas um de seus personagens e de modo algum representa a sua perspectiva global. Portanto, ao falarmos de "Pasolini" no âmbito deste ensaio, esperamos que o leitor tenha em mente que se trata apenas do Pasolini que se manifesta através de Quíron, e não de "todos os corpos de Pasolini".

${ }^{7}$ PASOLINI, P. P. Medea. Itália, 1969, 118 min.

${ }^{8}$ LUKÁCS, G. A teoria do romance. Tradução de José Marcos Mariani de Macedo. São Paulo: Duas Cidades/Editora 34, 2000, p. 28. 
${ }^{9}$ A odisséia de Visconti em sua busca por Tadzio encontra-se no filme Alla ricerca di Tadzio, dirigido pelo próprio Visconti. Itália, 1970, 30 min.

${ }^{10}$ MANN, T. Morte em Veneza. Tradução de Eloísa Ferreira Araújo Silva. Rio de Janeiro: Nova Fronteira, 2000, p. 29.

${ }^{11}$ Idem. Tonio Kröger. Tradução de Eloísa Ferreira Araújo Silva. Rio de Janeiro: Nova Fronteira, 2000, p. 115: "Quem acredita que um criador tem o direito de sentir é um ignorante. [...] Pois o sentimento sadio e vigoroso, está comprovado, desconhece o gosto."

12 Idem. Morte em Veneza. Op. cit., p. 51.

${ }^{13}$ VISCONTI, L. Morte a Venezia. Itália, 1971, $130 \mathrm{~min}$.

${ }^{14}$ Ibidem.

${ }^{15}$ MANN, T. Morte em Veneza. Op. cit., p. 38.

${ }^{16}$ Ibidem.

${ }^{17}$ VISCONTI, L. Morte a Venezia.

${ }^{18}$ BOILEAU, N. Arte poética. São Paulo: Perspectiva, 1979, p. 20.

${ }^{19}$ BENJAMIN, W. "Sobre o conceito de história". In: Obras escolhidas I. Tradução de Sergio Paulo Rouanet. São Paulo: Brasiliense, 1994, p. 226.

${ }^{20}$ Idem. "A obra de arte na era de sua reprodutibilidade técnica (Primeira Versão)". In: Op. cit., p. 196.

${ }^{21}$ Essa negatividade é tão marcante que resiste até mesmo à positivação da negatividade como traço mais marcante das manifestações artísticas contemporâneas, as quais demandam abordagens cada vez menos genéricas e mais singulares, empurrando a reflexão estética cada vez mais no sentido de uma estética aplicada, isto é, de filosofias da arte hauridas do confronto com obras de arte específicas e, a princípio, válidas apenas para a obra da qual brotaram.

${ }^{22}$ Cf. EAGLETON, T. A ideologia da estética. Rio de Janeiro: Jorge Zahar, p. 268: "A vanguarda tem dois momentos, um negativo e um positivo. O negativo é talvez o mais conhecido: choque, ultraje, bigodes na Monalisa. [...] O que é isso, em última instância, que a burguesia não pode suportar? A falta de sentido. Não ataque este ou aquele pedaço de significação ideológica, [...] ataque a própria estrutura e matriz da significação. [...] Há também o movimento positivo da vanguarda, o de Brecht mais do que o do dadaísmo. [...] Que coisa idealista imaginar que a arte, por si mesma, pudesse resistir à incorporação! A questão da apropriação tem a ver com política, não com cultura. [...] A única coisa de que a burguesia não tem como se apropriar é de sua derrota política. Veja se eles vão pendurar isso nas paredes dos bancos. A vanguarda negativa tenta evitar a absorção não produzindo objetos. Não há obras de arte, só gestos, happenings, manifestações, provocações. Não é possível integrar isso que se consome no mesmo instante da produção. A vanguarda positiva entende que a questão da integração está ligada ao destino do movimento político de massas".

${ }^{23}$ Aqui, talvez fosse importante mencionar que, a partir de Duchamp e da renúncia à identificação entre destreza técnica e valor estético, a categoria da "originalidade" alcançou uma importância que provavelmente jamais teve antes, nem mesmo na estética do gênio. Se, por um lado, essa originalidade relaciona-se com uma espécie de negação da tradição, assim podendo ser pensada como mais uma das tantas facetas da negatividade que atribuímos às obras de arte contemporâneas, por outro lado soa paradoxal a "exigência" de originalidade, que assim é elevada à categoria tradicional, e acaba por afirmar o que pretendia negar. A originalidade, além disso, está sempre na iminência de ser confundida com a pura novidade, característica central dos produtos da indústria cultural, de modo que, como categoria estética isolada, a originalidade não é suficiente para distinguir uma obra de arte. 
